\title{
Kształtowanie właściwości warstw wierzchnich kompozytowych TMMC w procesie azotowania laserowego gazowego stopu tytanu Ti6Al4V
}

\author{
Shaping the properties of the composite surface layers TMMC \\ during the process of laser gas nitriding of titanium alloy Ti6Al4V
}

\section{Streszczenie}

W artykule opisano wyniki badań procesu azotowania laserowego gazowego warstw wierzchnich stopu tytanu Ti6Al4V za pomocą lasera diodowego dużej mocy o emisji bezpośredniej (HPDDL), emitującego promieniowanie w zakresie bliskiej podczerwieni o długości fali $808 \mathrm{~nm}$, prostokątnym kształcie ogniska wiązki laserowej i równomiernym, wielomodowym rozkładzie energii TEM na przekroju ogniska. Dodatkowo wykonano próby azotowania z zastosowaniem lasera dyskowego o innej charakterystyce wiązki laserowej. Wyniki badań wykazały, iż możliwe jest wytworzenie za pomocą lasera HPDDL warstw wierzchnich kompozytowych Ti/TiNx o wysokiej twardości i bez pęknięć oraz kształtowanie właściwości i topografii powierzchni warstw wierzchnich w szerokim zakresie. W zależności od parametrów procesu i warunków technologicznych możliwe jest wytworzenie warstw wierzchnich o grubości od ok. 0,15 $\mathrm{mm}$ do ponad 1,6 mm, z wydzieleniami azotków tytanu $\delta$-TiN oraz $\varepsilon$-Ti2N rozmieszczonymi $\mathrm{w}$ osnowie metalicznej stopu tytanu Tia. Z kolei proces azotowania $\mathrm{z}$ zastosowaniem wiązki lasera dyskowego przebiega w sposób odmienny, a efekt azotowania warstw wierzchnich jest nieporównywalny do wyników uzyskanych przy zastosowaniu lasera HPDDL.

Słowa kluczowe: warstwy wierzchnie; warstwy kompozytowe; azotowanie laserowe; stop tytanu; Ti6Al4V

\section{Abstract}

The article describes the results of studies on the process of laser gas nitriding of surface layers on the titanium alloy Ti6AI4V conducted by means of continuous wave high power direct diode laser (HPDDL), which emits in the near infrared band at the wave length of $808 \mathrm{~nm}$, with a rectangular shape of the laser beam, and uniform, multimode TEM energy distribution across the laser beam. Additionally the trials of nitriding by the disk laser with different characteristic of the laser beam were conducted. The results showed that it is possible to produce the composite surface layers $\mathrm{Ti} / \mathrm{TiNx}$ by means of the HPDDL laser, characterized by high hardness and without cracks, and also it is possible to shape the properties and surface topography of the surface layers in a wide range. Depending on the process parameters and technological conditions it is possible to produce the surface layers having thickness from $0,15 \mathrm{~mm}$ up to or even over $1,6 \mathrm{~mm}$ with precipitations of titanium nitrides such as $\delta$-TiN and also $\varepsilon$-Ti2N evenly distributed in the metallic matrix of titanium alloy Tia. In turn, the process of surface layers nitriding by the disk laser is different and the results are not comparable to those obtained by application of the HPDDL laser.

Keywords: surface layers; composite layers; laser nitriding; titanium alloy; Ti6Al4V

\section{Wstęp}

Stopy tytanu pomimo, że posiadają wysokie właściwości mechaniczne w porównaniu z typowymi materiałami inżynierskimi, a szczególnie bardzo wysoki stosunek wytrzymałości do masy właściwej oraz doskonałą odporność korozyjną, cechują się niskimi właściwościami tribologicznymi, niską odpornością na zużycie w wyniku erozji oraz kawitacji [1 $\div 3$ ]. Ponadto posiadają wysoki współczynnik tarcia i cechują się skłonnością do tworzenia zadziorów, co znacznie ogranicza możliwość wykorzystania tytanu i jego stopów do produkcji części maszyn narażonych na zużycie w wyniku tarcia [2,3]. Z tego względu często konieczne jest zastosowanie dodatkowej obróbki warstw wierzchnich części wytwarzanych ze stopów tytanu tak, aby podwyższyć właściwości użytkowe powierzchni roboczych. Jedną z najbardziej oryginalnych i obiecujących metod modyfikacji właściwości warstw wierzchnich stopów tytanu jest azotowanie laserowe gazowe (ang. Laser Gas Nitriding - LGN). Dzięki dużej skłonności tytanu do absorpcji azotu w temp. powyżej $600{ }^{\circ} \mathrm{C}$ oraz wydzielania azotków w temp. powyżej $850{ }^{\circ} \mathrm{C}$ warstwa wierzchnia ulega silnemu naazotowaniu $\mathrm{w}$ wyniku nagrzewania i/lub przetapiania powierzchni tytanu oraz jego stopów wiązką laserową w atmosferze czystego azotu lub też mieszaniny azotu z gazem obojętnym, np. argonem. Pierwsze próby azotowania laserowego gazowego tytanu wykonał Katayama [1] już w latach osiemdziesiątych minionego wieku, przy zastosowaniu dostępnego wówczas lasera gazowego $\mathrm{CO}_{2}$ o emisji ciągłej (ang. continuous wave - $\mathrm{cw}$ ). Z uwagi na ogromny potencjał tej technologii, jak również ciągły i dynamiczny rozwój urządzeń laserowych badania w zakresie

Dr inż. Aleksander Lisiecki - Politechnika Śląska, Katedra Spawalnictwa; dr inż. Agnieszka Kurc-Lisiecka - Wyższa Szkoła Biznesu w Dąbrowie Górniczej, Katedra Transportu Szynowego.

Autor korespondencyjny/Corresponding author: alisiecka@wsb.edu.pl 
azotowania laserowego gazowego stopów tytanu prowadzane

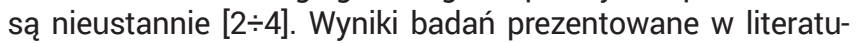
rze światowej wskazują jednoznacznie, że zarówno typ lasera oraz parametry jego pracy mają ogromny wpływ na przebieg procesu azotowania gazowego tytanu i stopów tytanu oraz

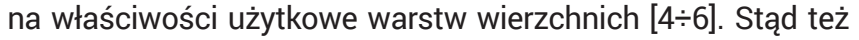
podjęto szczegółowe badania o szerokim zakresie dotyczące zastosowania lasera diodowego o emisji bezpośredniej i unikatowych właściwościach promieniowania oraz prostokątnej wiązki laserowej w procesie azotowania powszechnie stosowanego stopu tytanu Ti6Al4V.

\section{Przebieg i wyniki badań}

Celem badań była analiza możliwości kształtowania właściwości i topografii powierzchni warstw wierzchnich na podłożu stopu tytanu Ti6Al4V za pomocą lasera diodowego HPDDL (high power direct diode laser) ROFIN DL 020 o prostokątnym ognisku wiązki laserowej, równomiernym rozkładzie modowym energii na przekroju poprzecznym ogniska TEM oraz długości fali $808 \mathrm{~nm}$, w porównaniu do wiązki lasera dyskowego o kołowym przekroju wiązki laserowej i długości fali $1030 \mathrm{~nm}$ oraz rozkładzie modowym zbliżonym do rozkładu gaussowskiego TEM00. Wiązkę lasera diodowego HPDDL o wymiarach ogniska 6,8x1,8 mm ogniskowano na górnej powierzchni płytek i przemieszczano ruchem prostoliniowym o zadanej prędkości w taki sposób, że dłuższy bok ogniska wiązki laserowej był ustawiony poprzecznie do kierunku przesuwu. W efekcie możliwe było utworzenie pojedynczego ściegu o szerokości ok. 6,0 do $6,5 \mathrm{~mm}$. Z kolei w przypadku lasera dyskowego o średnicy ogniska $200 \mu \mathrm{m}$ wiązkę rozogniskowano zwiększając odległość głowicy od płytki tak, aby średnica wiązki laserowej na górnej powierzchni płytki była równa $6,8 \mathrm{~mm}$, a szerokość obszaru nagrzewanego wiązką lasera dyskowego był taki sam, jak w przypadku lasera diodowego HPDDL. Badania azotowania laserowego wykonano na płytkach ze stopu tytanu o wymiarach 70x40 mm i grubości 3,0 mm. Płytki umieszczano w komorze, do której doprowadzano azot o wysokiej czystości (99,999\%) pod ciśnieniem nieznacznie wyższym od ciśnienia atmosferycznego tak, aby zapewnić swobodny przepływ azotu przez zawory spustowe w tylnej ścianie komory na poziomie ok. 5,0 l/min (rys. 1). Wiązkę lasera HPDDL doprowadzano do powierzchni nagrzewanej płytki poprzez szczelną pokrywę ze szkła akrylowego (PMMA, potocznie pleksi), które jest prawie zupełnie przeźroczyste dla promieniowania lasera diodowego. Z kolei w przypadku lasera dyskowego transmisja wiązki laserowej o mocy powyżej 1,8 kW przez pokrywę nie była możliwa z powodu intensywnego nagrzewania i w konsekwencji uszkodzenia pokrywy, zarówno ze szkła akrylowego, jak również ze szkła kwarcowego. Z tego powodu konieczne było wykonanie specjalnej śluzy gazowej w pokrywie komory, przez którą wiązka lasera dyskowego doprowadzana była do wnętrza i do powierzchni płytki (rys. 1d). W celu usunięcia powietrza z wnętrza komory przepływ azotu włączano $z$ wyprzedzeniem co najmniej 3 minut przed rozpoczęciem procesu azotowania, tj. włączenia wiązki laserowej i nagrzewania płytki. Powierzchnie płytek czyszczono mechanicznie oraz odtłuszczano za pomocą acetonu. W pierwszym etapie badań wykonano próby azotowania płytek ze stopu tytanu za pomocą lasera diodowego HPDDL. Warstwy wierzchnie wykonywano pojedynczymi ściegami prostymi w szerokim zakresie parametrów, a następnie dla wybranych parametrów procesu azotowania wykonano warstwy wierzchnie wielościegowe z zakładką ok. $20 \div 25 \%$. W kolejnym etapie badań podjęto próby azotowania warstw wierzchnich za pomocą lasera dyskowego w taki sposób, aby szerokość pojedynczego ściegu prostego była taka, jak w przypadku lasera diodowego HPDDL.
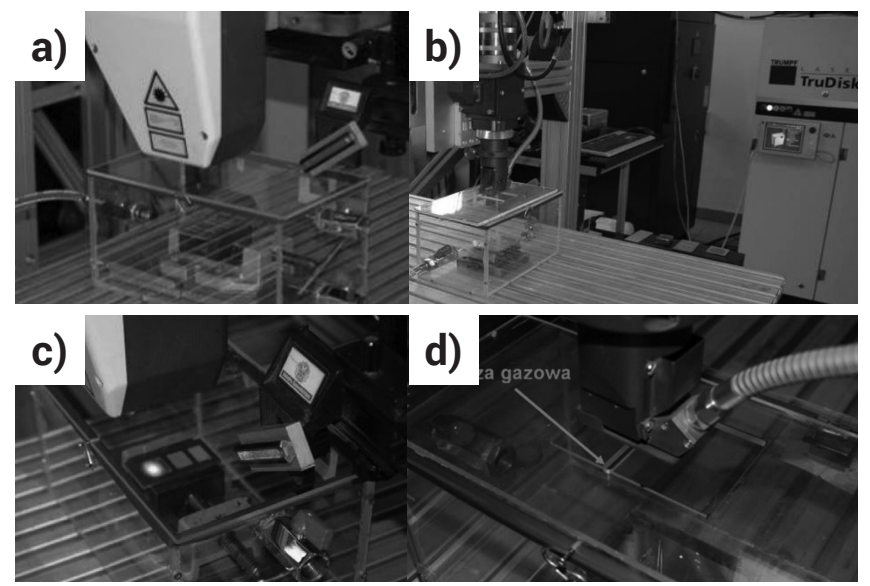

Rys. 1. Widok stanowiska badawczego do azotowania laserowego gazowego z laserem diodowym HPDDL (a) i dyskowym TruDisk (b) oraz widok procesu azotowania płytki ze stopu tytanu laserem HPDDL w komorze wypełnionej azotem (c) i śluzy gazowej do transmisji wiązki lasera dyskowego

Fig. 1. A view of the experimental stand for laser gas nitriding by the diode laser HPDDL (a) and the disk laser TruDisk (b) and also a view of the nitriding process of the titanium alloy plate conducted by the HPDDL laser in the chamber fulfilled with nitrogen (c) and the gas sluice for transmission of the disk laser beam

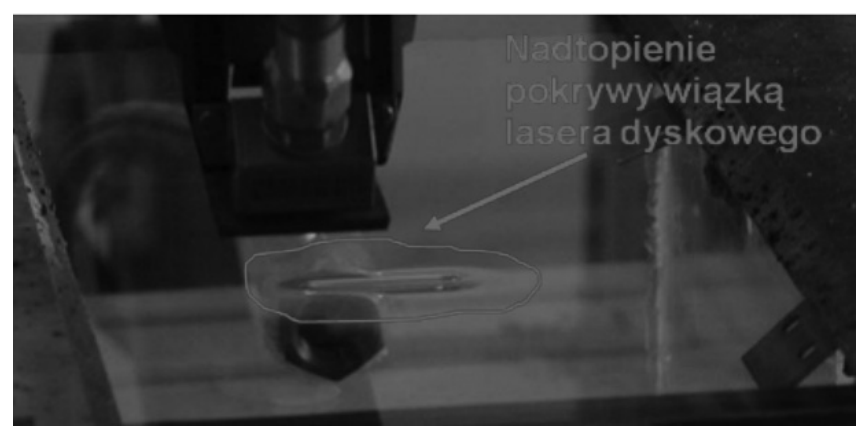

Rys. 2. Widok szklanej pokrywy komory uszkodzonej w wyniku działania wiązki lasera dyskowego

Fig. 2. A view of the glass cover of a chamber damaged by the interaction of the disk laser

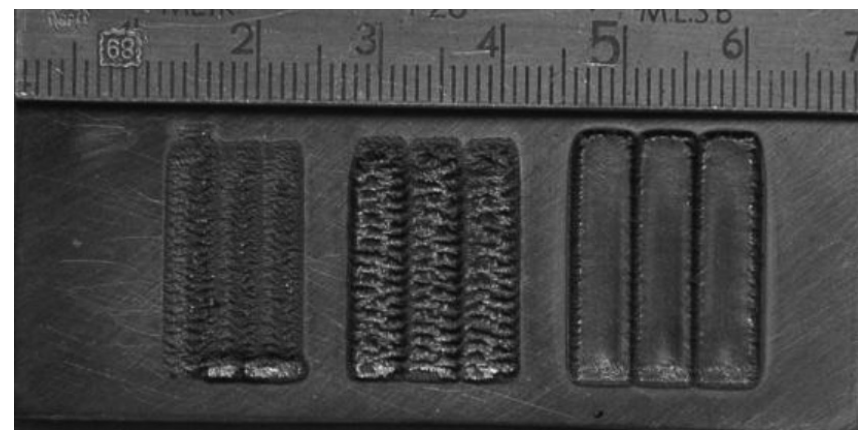

Rys. 3. Widok warstw wierzchnich wielościegowych wytworzonych za pomocą lasera diodowego HPDDL (parametry azotowanie od lewej P20, P12, P16)

Fig. 3. A view of multi-bead surface layers produced by means of diode laser HPDDL (parameters of nitriding from left P20, P12, P16)

\section{Analiza wyników badań}

Próby azotowania laserowego gazowego (ang. Laser Gas Nitriding - LGN) płytek ze stopu tytanu Ti6Al4V o grubości 3,0 mm za pomocą lasera diodowego o emisji bezpośredniej HPDDL i prostokątnym przekroju ogniska wiązki laserowej o wymiarach 6,8x1,8 mm w atmosferze gazowej czystego azotu prowadzą do wytworzenia warstwy wierzchniej o połysku metalicznym, złotej barwie i regularnej topografii powierzchni (rys. 1,3). W przypadku zogniskowania prostokątnej wiązki lasera HPDDL na górnej powierzchni płytki, ustawionej poprzecznie (dłuższym bokiem o szerokości 6,8 mm) do kierunku przesuwu (skanowania) i nad- 
Tablica I. Parametry procesu azotowania laserowego gazowego płytek ze stopu tytanu Ti6Al4V za pomocą lasera HPDDL oraz dyskowego TruDisk Table I. The process parameters of laser gas nitriding of titanium alloy Ti6Al4V plates by means of HPDDL laser and disk laser TruDisk

\begin{tabular}{|c|c|c|c|c|c|c|}
\hline \multirow[t]{2}{*}{ Nr ściegu } & \multirow[t]{2}{*}{$\begin{array}{l}\text { Prędkość skanowania } \\
\text { [mm/min] }\end{array}$} & \multirow[t]{2}{*}{$\begin{array}{l}\text { Moc wiązki laserowej } \\
\text { [W] }\end{array}$} & \multirow[t]{2}{*}{$\begin{array}{c}\text { Energia liniowa } \\
{[\mathrm{J} / \mathrm{mm}]}\end{array}$} & \multicolumn{2}{|c|}{$\begin{array}{l}\text { Gęstość mocy } \\
\text { wiązki lasera } \\
\text { [W/cm²] }\end{array}$} & \multirow{2}{*}{$\begin{array}{c}\text { Grubość warstwy } \\
\text { azotowanej laserem } \\
\text { HPDL } \\
\text { [mm] }\end{array}$} \\
\hline & & & & HPDDL* & TruDisk* & \\
\hline $\mathrm{P} 1$ & 200 & 500 & 150 & $4 \cdot 10^{3}$ & $1,37 \cdot 10^{3}$ & 0,04 \\
\hline $\mathrm{P} 2$ & 600 & 1800 & 180 & $1,5 \cdot 10^{4}$ & $4,96 \cdot 10^{3}$ & 1,08 \\
\hline P3 & 400 & 1200 & 180 & $0,98 \cdot 10^{4}$ & $3,3 \cdot 10^{3}$ & 0,98 \\
\hline P4 & 200 & 600 & 180 & $0,49 \cdot 10^{4}$ & $1,6 \cdot 10^{3}$ & 0,90 \\
\hline P5 & 200 & 700 & 210 & $0,57 \cdot 10^{4}$ & $1,93 \cdot 10^{3}$ & 1,08 \\
\hline P6 & 1000 & 2000 & 120 & $1,6 \cdot 10^{4}$ & $5,5 \cdot 10^{3}$ & 0,26 \\
\hline P7 & 900 & 1800 & 120 & $1,5 \cdot 10^{4}$ & $4,95 \cdot 10^{3}$ & 0,24 \\
\hline P8 & 600 & 1200 & 120 & $0,98 \cdot 10^{4}$ & $3,3 \cdot 10^{3}$ & 0,28 \\
\hline P9 & 300 & 600 & 120 & $0,49 \cdot 10^{4}$ & $1,6 \cdot 10^{3}$ & 0,05 \\
\hline P10 & 800 & 2000 & 150 & $1,6 \cdot 10^{4}$ & $5,5 \cdot 10^{3}$ & 0,79 \\
\hline P11 & 600 & 1500 & 150 & $1,2 \cdot 10^{4}$ & $4,13 \cdot 10^{3}$ & 0,67 \\
\hline $\mathrm{P} 12$ & 1000 & 1500 & 90 & $1,2 \cdot 10^{4}$ & $4,13 \cdot 10^{3}$ & 0,14 \\
\hline P13 & 800 & 1200 & 90 & $0,98 \cdot 10^{4}$ & $3,3 \cdot 10^{3}$ & 0,17 \\
\hline $\mathrm{P} 14$ & 600 & 900 & 90 & $0,74 \cdot 10^{4}$ & $2,48 \cdot 10^{3}$ & 0,13 \\
\hline P15 & 400 & 600 & 90 & $0,49 \cdot 10^{4}$ & $1,6 \cdot 10^{3}$ & 0,02 \\
\hline P16 & 400 & 1800 & 270 & $1,5 \cdot 10^{4}$ & $4,95 \cdot 10^{3}$ & 1,74 \\
\hline P17 & 200 & 900 & 270 & $0,74 \cdot 10^{4}$ & $2,48 \cdot 10^{3}$ & 0,67 \\
\hline P18 & 2000 & 2000 & 60 & $1,6 \cdot 10^{4}$ & $5,5 \cdot 10^{3}$ & 0,19 \\
\hline P19 & 1800 & 1800 & 60 & $1,5 \cdot 10^{4}$ & $4,95 \cdot 10^{3}$ & 0,09 \\
\hline P20 & 1500 & 1500 & 60 & $1,2 \cdot 10^{4}$ & $4,13 \cdot 10^{3}$ & 0,14 \\
\hline
\end{tabular}

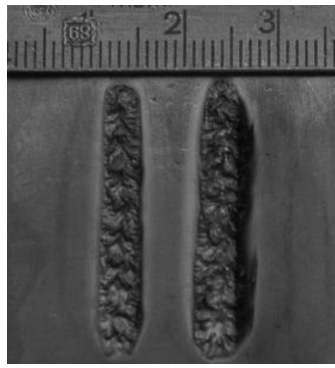

Rys. 4. Widok warstw wierzchnich jednościegowych wytworzonych za pomocą lasera dyskowego TruDisk (prędkość skanowania $400 \mathrm{~mm} / \mathrm{min}$, moc wiązki laserowej od lewej $1,8 \mathrm{~kW}, 2,0 \mathrm{~kW}$ )

Fig. 4. A view of the single-bead surface layers produced by means of disk laser TruDisk (scanning speed $400 \mathrm{~mm} / \mathrm{min}$, laser power from left 1,8 kW, 2,0 kW) a)
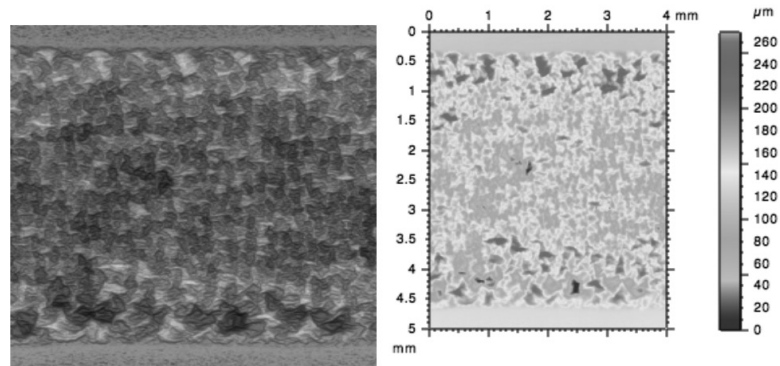

b)
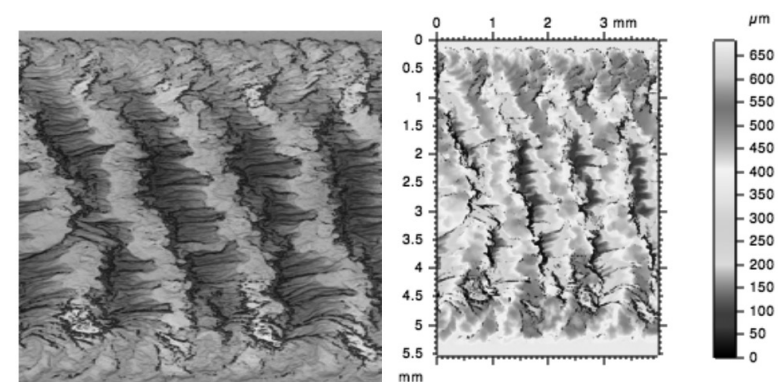

c)

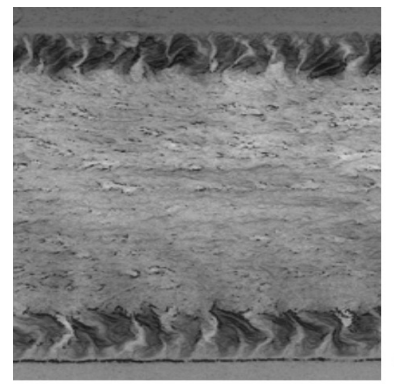

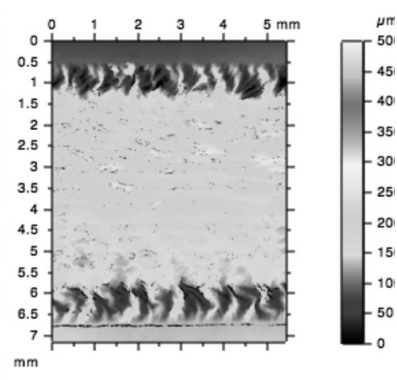

Rys. 5. Widok warstw wierzchnich wielościegowych wytworzonych za pomocą lasera diodowego HPDDL (parametry azotowanie od lewej P20, P12, P16)

Fig. 5. A view of multi-bead surface layers produced by means of diode laser HPDDL (parameters of nitriding from left P20, P12, P16) 
a)

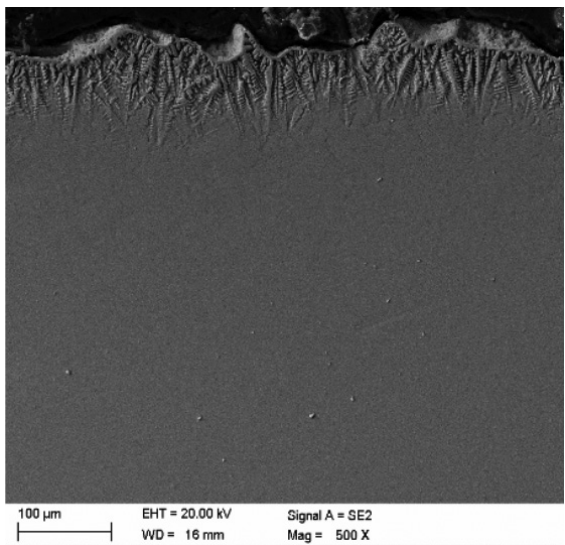

b)

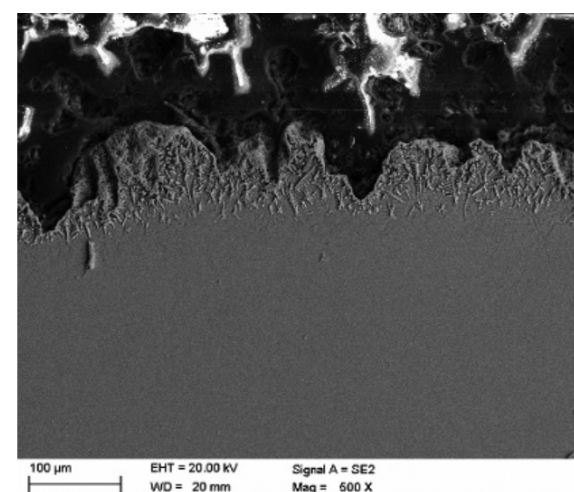

c)

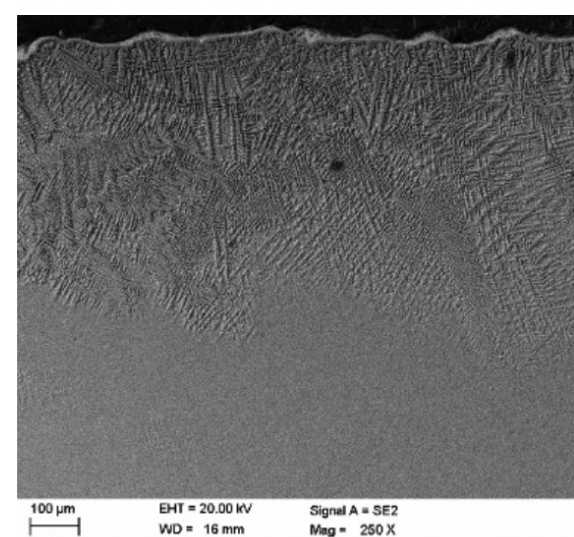

Rys. 6. Widok warstw wierzchnich wielościegowych wytworzonych za pomocą lasera diodowego HPDDL (parametry azotowanie od lewej P20, P12, P16)

Fig. 6. A view of multi-bead surface layers produced by means of diode laser HPDDL (parameters of nitriding from left P20, P12, P16)

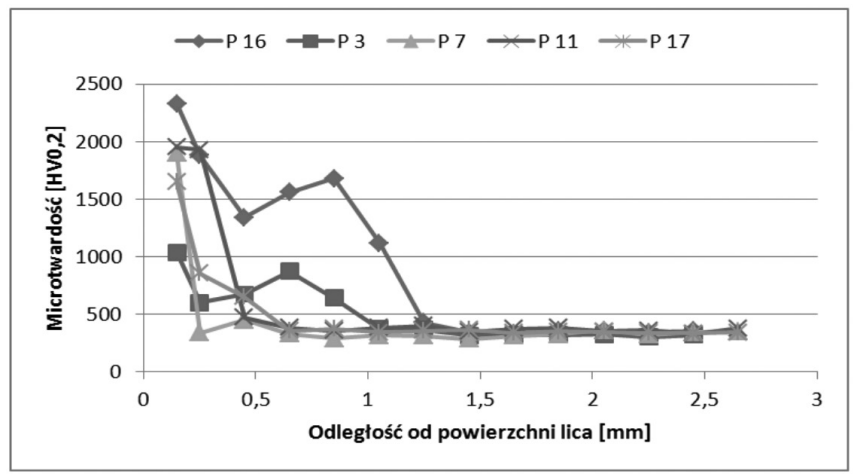

Rys. 7. Rozkład mikrotwardości na przekroju poprzecznym warstw wierzchnich azotowanych laserem HPDDL (tabl. I)

Fig. 7. Microhardness distribution across the surface layers nitrided by the HPDDL laser (table I)

tapiania powierzchni płytki szerokość pojedynczego ściegu mieści się w zakresie 5,8 do 6,0 mm, w zależności od parametrów przetapiania (tabl. I, rys. 3). Zmiana parametrów procesu azotowania z zastosowaniem wiązki lasera HPDDL, głównie mocy wiązki laserowej i prędkości skanowania, umożliwia zmianę

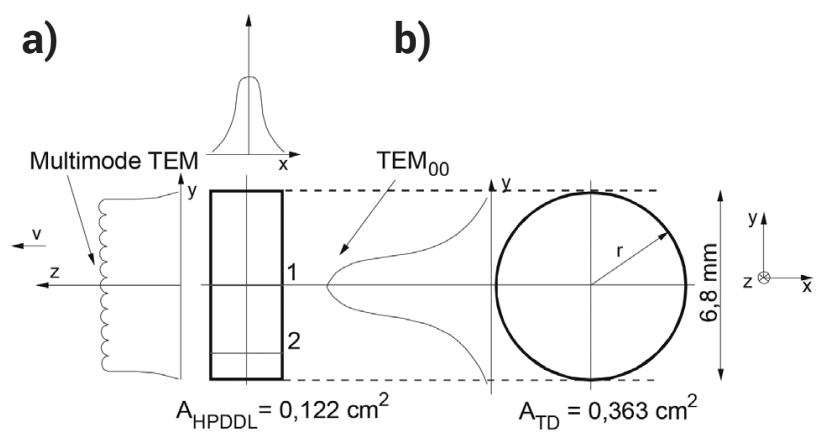

Rys. 8. Porównanie kształtu wiązki laserowej na górnej powierzchni nagrzewanej płytki ze stopu tytanu oraz rozkładu energii (TEM) na przekroju poprzecznym wiązki lasera HPDDL (a) oraz dyskowego TruDisk - TD (b)

Fig. 8. The comparison of the laser beam shape on the top surface of the heated titanium alloy plate and transverse electromagnetic mode (TEM) across the laser beam of HPDDL (a) and the disk laser TruDisk - TD (b)

i precyzyjne sterowanie topografią powierzchni warstw wierzchnich. Dotychczasowe badania procesu azotowania gazowego wiązką lasera HPDDL opisane w pozycji literaturowej [4] wykazały, że energia liniowa nie jest parametrem wystarczającym do precyzyjnego sterowania i prognozowania właściwościami oraz topografią warstw wierzchnich na podłożu stopu tytanu. W tym przypadku znacznie wyższą zgodność i zbieżność wyników zapewnia odniesienie do gęstości mocy wiązki laserowej na górnej powierzchni nagrzewanej płytki oraz czasu oddziaływania wiązki laserowej na tej powierzchni (proporcjonalnie do prędkości skanowania). W przypadku względnie dużych prędkości skanowania powierzchni płytki ze stopu tytanu Ti6Al4V wiązką lasera HPDDL na poziomie $1500 \mathrm{~mm} / \mathrm{min}$ i przy mocy $1500 \mathrm{~W}$, płytka ulega równomiernemu nadtopieniu na całej szerokości ściegi, a topografia powierzchni warstwy wierzchniej jest regularna o wysokościach nierówności do $200 \mu \mathrm{m}$ długości (rys. 5a). Z kolei przy niższych prędkościach skanowania ok. $1000 \mathrm{~mm} / \mathrm{min}$ powierzchnia warstwy wierzchniej staje się nieregularna i występują na niej powtarzające się cyklicznie o całkowitej wysokości nierówności rzędu 650 um (rys. 5b). Dalsze zmniejszenie prędkości skanowania wiązką lasera HPDDL do $400 \mathrm{~mm} / \mathrm{min}$ powoduje kolejną zmianę topografii powierzchni. Powierzchnia warstwy wierzchniej azotowanej w takich warunkach staje się płaska i równa, a maksymalna wysokość nierówności nie przekracza $150 \mu \mathrm{m}$ (rys. 5c). W wyniku obserwacji i badań wizualnych nie stwierdzono pęknięć na powierzchniach wszystkich próbnych warstw wierzchnich wykonanych pojedynczymi ścigami prostymi (rys. 5). Próby wytwarzania warstw wierzchnich ściegami prostymi zakosowymi z zakładką ok. $15 \div 0 \%$ wykazały, że możliwe jest również wytworzenie warstw wielościegowych oraz precyzyjne sterowanie topografią tych warstw (rys. 3). Podobnie jak w przypadku pojedynczych ściegów prostych w przypadku warstw wielościegowych nie stwierdzono pęknięć powierzchniowych. Badania metalograficzne ściegów prostych wytworzonych za pomocą wiązki lasera HPDDL nie ujawniły pęknięć na przekroju poprzecznym (rys. 3). Warstwy wierzchnie posiadają strukturę kompozytową z wydzieleniami dendrytycznych azotków tytanu osadzonych w osnowie metalicznej (ang. titanium metal matrix composite - TMMC) o morfologii i głębokości warstwy przypowierzchniowej bogatej w wydzielenia azotków tytanu zależnej od parametrów procesu azotowania (rys. 6). Z kolei mikrotwardość na przekroju poprzecznym warstw wierzchnich azotowanych sięga prawie 2400 HV0,2 w przypadku warstwy wykonanej przy prędkości skanowania 400 mm/min i mocy 1800 W (najwyższej energii liniowej $270 \mathrm{~J} / \mathrm{mm}$ ), której głębokość jest równa 1,6 $\div 1,7$ mm (rys. 7). Rozkład oraz wartości maksymalne mikrotwardości zależne są od głębokości i morfologii warstw azotowanych (rys. 7). 
Wyniki pomiarów wskazują też, że mikrotwardość na przekroju poprzecznym badanych warstw wierzchnich osiąga najwyższą wartość bezpośrednio pod górną powierzchnią (lica), a następnie stopniowo obniża się do wartości mikrotwardości materiału podłoża, tj. ok. 360 HV0,2. Zjawisko to związane jest z rozmieszczeniem azotków i ich udziałem względem osnowy metalicznej (rys. 6). W strefie przypowierzchniowej udział azotków tytanu względem osnowy jest najwyższy, dlatego też mikrotwardość osiąga w tej strefie najwyższą wartość. Z kolei wraz ze wzrostem głębokości maleje udział azotków o wysokiej twardości w stosunku do osnowy o znacznie niższej twardości (rys. 6).

Próby azotowania z zastosowaniem lasera dyskowego TruDisk, o zupełnie innej charakterystyce i przekroju kołowym wiązki laserowej, prowadzono tak, aby odwzorować warunki wytwarzania warstwy P16 przy mocy 1,8 kW i prędkości skanowania $400 \mathrm{~mm} / \mathrm{min}$ (tabl. I). Wiązkę lasera dyskowego rozogniskowano $w$ taki sposób, aby jej średnica na górnej powierzchni płytki ze stopu tytanu była równa szerokości wiązki lasera HPDDL, tj. 6,8 mm (tabl. I, rys. 8). Wstępne próby azotowania płytek umieszczonych w komorze zamkniętej szczelnie przeźroczystą pokrywą ze szkła akrylowego PMMA wykazały, że przy mocy wiązki lasera dyskowego 1,8 kW pokrywa ulega silnemu nagrzaniu i nadtopieniu w miejscu transmisji wiązki laserowej o długości fali $1030 \mathrm{~nm}$, czyli zaledwie o ok. $220 \mathrm{~nm}$ dłuższej niż lasera HPDDL (dominująca długość fali $808 \mathrm{~nm}$ ). Próby z pokrywą ze szkła kwarcowego dały podobny efekt, czyli doprowadziły do nagrzania i pęknięcia pokrywy szklanej (rys. 2). Powodem tego zjawiska jest wyraźnie niższy stopień przeźroczystości (transmisji) szkła akrylowego PMMA oraz szkła kwarcowego w przypadku promieniowania laserowego o długości 1030 nm, co prowadzi do częściowej absorpcji promieniowania przez pokrywę i w jej nagrzewanie. Przy wysokich mocach wiązki laserowej, ok. 1,8 kW intensywność nagrzewania wzrasta i prowadzi do uszkodzenia pokrywy. W związku z tym dalsze próby kontynuowano transmitując wiązkę za pomocą specjalnie wykonanej śluzy gazowej, przez którą wypływał swobodnie azot doprowadzony do komory pod ciśnieniem nieznacznie wyższym od ciśnienia atmosferycznego (rys. 1d). Warstwa wierzchnia wytworzona w ten sposób za pomocą wiązki lasera dyskowego posiada wyraźnie odmienną topografię powierzchni, w porównaniu do warstw wytworzonych laserem HPDDL (rys. 3 do 5). Dodatkowo szerokość ściegu nie jest jednakowa na jego długości, a topografia powierzchni jest nieregularna o znacznych wysokościach nierówności (rys. 4). Zwiększenie mocy wiązki lasera dyskowego do 2,0
kW (czyli maksymalnej mocy, przy której prowadzono próby za pomocą lasera HPDDL) nie spowodowało wyraźnego wpływu na kształt ściegu i topografię powierzchni warstwy wierzchniej (rys. 4). Tak więc efekty wykonanych prób azotowania laserowego płytek ze stopu tytanu Ti6Al4V za pomocą wiązki lasera dyskowego TruDisk o przekroju kołowym i wiązki lasera diodowego HPDDL o przekroju prostokątnym nie są porównywalne. W badanym zakresie mocy wiązki laserowej do 2,0 kW oraz energii liniowej procesu azotowania do 270 $\mathrm{J} / \mathrm{mm}$ zastosowanie kołowej wiązki lasera dyskowego o średnicy $6,8 \mathrm{~mm}$ nie pozwala na wytworzenie warstw wierzchnich o szerokości pojedynczego ściegu ok. 6,0 mm o gładkiej i regularnej powierzchni, jak w przypadku prostokątnej wiązki lasera HPDDL. Powodem tego zjawiska są odmienne warunki nagrzewania i nadtapiania płytki za pomocą obydwu wiązek laserowych. W przypadku wiązki lasera dyskowego o kołowym przekroju oraz rozkładzie energii na przekroju poprzecznym wiązki TEM zbliżonym do gaussowskiego nagrzewanie powierzchni na drodze przesuwu wiązki jest nierównomierne. Ponadto czas oddziaływania wiązki (promieniowania laserowego) na przekroju poprzecznym ściegu jest różny. Najdłuższy czas oddziaływania promieniowania laserowego występuje w osi przesuwu wiązki, a w punktach skrajnych zewnętrznych ściegu czas oddziaływania wiązki jest bliski 0 (rys. 8). Dodatkowo współczynnik absorpcji promieniowania laserowego o długości fali jest nieco niższy w porównaniu do lasera diodowego, co powoduje, że sprawność przekazywania energii cieplnej i nagrzewania płytki jest niższa. Jednak najistotniejsza różnica w oddziaływaniu promieniowania obydwu laserów wynika z pola przekroju poprzecznego wiązki odpowiednio o szerokości i średnicy 6,8 mm. Pole przekroju kołowej wiązki lasera dyskowego TruDisk jest prawie trzykrotnie większe $\left(0,363 \mathrm{~cm}^{2}\right)$ przy średnicy $6,8 \mathrm{~mm}$ w porównaniu do prostokątnego przekroju $\left(0,122 \mathrm{~cm}^{2}\right)$ wiązki lasera diodowego o szerokości 6,8 mm i długości 1,8 mm (rys. 8). Ponieważ gęstość mocy wiązki laserowej jest wprost proporcjonalna do jej pola przekroju poprzecznego, to oznacza, że gęstość mocy wiązki lasera dyskowego o średnicy $6,8 \mathrm{~mm}$ na powierzchni płytki jest trzykrotnie niższa $\left(4,95 \cdot 10^{3}\right)$ niż wiązki lasera diodowego $\left(1,5 \cdot 10^{4}\right)$ o szerokości $6,8 \mathrm{~mm}$ (rys. 8, tabl. I). W dotychczasowych badaniach i wcześniejszych publikacjach wykazano, że to nie energia liniowa, a właśnie gęstość mocy wiązki laserowej oraz jej czas oddziaływania na powierzchnię wywiera istotny wpływ na mechanizm nagrzewania, nadtapiania, a w związku

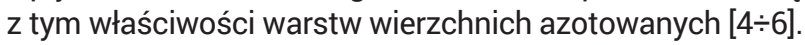

\section{Podsumowanie}

Badania procesu azotowania laserowego gazowego LGN płytek ze stopu tytanu Ti6Al4V wykazały, że zastosowanie wiązki lasera diodowego HPDDL, emitującego promieniowanie o długości fali $808 \mathrm{~nm}$, o prostokątnym kształcie ogniska wiązki laserowej i równomiernym, wielomodowym rozkładzie energii TEM na przekroju ogniska, umożliwia wytworzenie warstw wierzchnich kompozytowych o wysokiej twardości i bez pęknięć oraz pozwala na kształtowanie właściwości i topografii powierzchni warstw wierzchnich w szerokim zakresie. Z kolei efekty prób azotowania warstw wierzchnich z zastosowaniem wiązki lasera dyskowego TruDisk są odmienne i nie porównywalne z wynikami badań w przypadku zastosowania wiązką lasera diodowego. Wynika to z różnej charakterystyki promieniowania obydwu laserów, różnego kształtu wiązki laserowej i różnego rozkładu energii na przekroju poprzecznym wiązki TEM, co z kolei skutkuje różnym sposobem i intensywnością nagrzewania oraz nadtapiania powierzchni.

\section{Literatura}

[1] S. Katayama et al.: Surface hardening of titanium by laser nitriding, in Laser Processing of Materials, ICALEO'83, Conf. Proc., Los Angles, USA, pp. 127-134, 1983.

[2] R. Filip: Laser nitriding of the surface layer of Ti6Al4V titanium alloy, Arch Mater. Sci. Eng. 30, 2008.

[3] R. Filip, J. Sieniawski: Mikrostruktura i właściwości użytkowe warstwy wierzchniej stopu tytanu Ti-6Al-4V kształtowanej metodą stopowania laserowego, Inżynieria Materiałowa Nr 3, 2006.

[4] A. Lisiecki: Titanium Matrix Composite Ti/TiN Produced by Diode Laser Gas Nitriding, Metals 5(1), pp. 54-69, 2015, doi:10.3390/met5010054.

[5] A. Lisiecki: Mechanism of Laser Surface Modification of the Ti-6Al-4V Alloy in nitrogen atmosphere using a High Power Diode Laser, Advanced Materials Research 1036, pp. 411-416, 2014, doi:10.4028/www.scientific. net/AMR.1036.411.

[6] A. Lisiecki: Experimental and numerical study of heat conditions during diode laser gas nitriding of titanium alloy, Adv. Mater. Res. 1036, pp. 320-325, 2014, doi:10.4028/www.scientific.net/AMR.1036.320. 